\title{
Low frequency of HLA-DRB 1 * 11 in hepatitis C virus induced end stage liver disease
}

H L Tillmann, D-F Chen, C Trautwein, V Kliem, A Grundey, A Berning-Haag, K Böker, S Kubicka, L Pastucha, W Stangel, M P Manns are likely to modulate $\mathrm{HCV}$ induced liver disease. The importance of genetic factors for $\mathrm{HCV}$ infection arises from the observation of different courses of infection despite the same source of infection. ${ }^{9}$ Crucial genetic factors influencing the immune reaction are the human leucocyte antigens (HLAs) encoded by the major histocompatibility complex (MHC). Recent studies have indicated an important role for the MHC class II antigen HLA-DR13 in viral clearance of hepatitis $B,{ }^{11}{ }^{11}$ and there is evidence of disease modulation in human immunodeficiency virus (HIV) infection. ${ }^{12}{ }^{13}$ However, associations between HLA determinants and susceptibility to $\mathrm{HCV}$ remain controversial. While some studies did not reveal any significant associations, ${ }^{14-17}$ others highlighted the relevance of the serologically determined HLA-DR5 antigen or the corresponding DNA determined HLA-DRB1* 11 alleles in chronic hepatitis $\mathrm{C}^{18-21}$ and some found other antigens such as $\mathrm{DRB} 1^{\star} 09,{ }^{22} 23$ HLA-DR $13,{ }^{24}$ DRB $1{ }^{\star} 04$, DQB $1{ }^{\star} 03^{25}$ or $\mathrm{DRB} 1^{\star} 1301$, and $\mathrm{DQA} 1^{\star} 0103^{26}$ associated with viral clearance of $\mathrm{HCV}$ infection.

HLA antigen frequency in patients with $\mathrm{HCV}$ induced end stage liver disease with or without HCC has not been addressed previously in European patients. These patients with HCV infection clearly have a poor outcome. Any HLA association relevant for chronicity or disease progression should become evident in these patients unless the mechanisms involved in viral persistence are contrary to those involved in promoting hepatocellular damage. Therefore, these patients are especially appropriate for studying the relevance of HLA antigens in HCV dependent disease progression.

Thus we analysed the phenotype frequencies of class I and class II HLA antigens in two such patient groups. Additionally, we studied the relation of $\mathrm{HCV}$ genotype and presence of HCC to HLA antigens.

\section{Patients and methods}

PATIENTS

The first part of the study involved 69 Caucasians who had undergone liver transplantation for $\mathrm{HCV}$ induced end stage liver cirrhosis at Hannover Medical School between January 1984 and June 1996. In patients transplanted

Hepatitis C virus (HCV) infection leads to the development of chronic hepatitis in about $70-80 \%$ of cases, ${ }^{1-4}$ of whom $20-30 \%$ progress to liver cirrhosis or hepatocellular carcinoma (HCC). ${ }^{5}$ The liver damage in $\mathrm{HCV}$ infected patients is probably mediated by both direct cytopathic effects and immune mediated mechanisms. ${ }^{6} \mathrm{HCV}$ genotype and viral load ${ }^{8}$
Abbreviations used in this paper: HCC hepatocellular carcinoma; HCV, hepatitis $\mathrm{C}$ virus; HBV, hepatitis B virus; HLA, human leucocyte antigen; HIV, human immunodeficiency virus; MHC, major histocompatibility complex; PCR, polymerase chain reaction; $\mathrm{RR}$, relative risk; $\mathrm{SSO}$, sequence specific oligonucleotide. 
since $1992 \mathrm{HCV}$ serology was tested prospectively by antibodies and polymerase chain reaction (PCR) while the HCV status of patients transplanted before 1992 was determined retrospectively from sera stored at $-80^{\circ} \mathrm{C} .{ }^{27}$ Patients with evidence of another cause of liver cirrhosis other than HCV infection were excluded from the study, especially those with viral coinfection with hepatitis B virus (HBV) and known alcohol consumption. There were 26 females and 43 males. The frequencies of the different HLA phenotypes were compared with 331 unrelated blood and organ donors registered at our blood bank or whose livers were transplanted between 1984 and 1995.

To confirm the significance of our results, we analysed a second group of 39 patients transplanted for or suffering from $\mathrm{HCV}$ induced end stage liver cirrhosis requiring liver transplantation compared with 170 unrelated blood donors (unrelated and different from control group 1) registered at our blood bank who were repeated blood donors with normal transaminases and no markers for $\mathrm{HCV}$ or HBV infection. Patients with end stage liver disease had signs of decompensation, severe impairment of liver function, and advanced cirrhosis. There were 17 females and 22 males in this group.

In 79 of 108 patients the histological diagnosis of HCC or its absence was available for evaluation because the explanted liver was examined. Twenty two patients had evidence of HCC while 57 had no evidence of HCC in explanted livers. HCV genotype was determined in 73 of 108 cases while the genotype was not available in the other patients because an appropriate serum sample was not available. HCV genotypes were determined as described previously. ${ }^{28}{ }^{29}$ Thus the minimal breakdown of HCV genotypes was $1 \mathrm{a}(\mathrm{n}=8), 1 \mathrm{~b}(\mathrm{n}=53)$ and $2 \mathrm{a}$, and $2 \mathrm{~b}$ and $3 \mathrm{a}(\mathrm{n}=12)$. As most patients showed genotype $1 \mathrm{a}$ or $1 \mathrm{~b}$, we compared three groups according to genotype $1 \mathrm{a}, 1 \mathrm{~b}$, or neither of these. Furthermore, we compared all patients with genotype 1 versus those with other genotypes and all patients with genotype $1 \mathrm{~b}$ versus all others.

VIROLOGICAL PARAMETERS

Serological markers for HBV, HCV, and hepatitis $\mathrm{D}$ virus infection were determined using commercial assays (Abbott Laboratories, Illinois, USA). HCV-RNA and HBV-DNA were detected as described previously. ${ }^{30} 31$

HLA TYPING

HLA antigens of both class I and class II were serologically determined by standard microlymphocytotoxicity assay in our laboratory for tissue typing using both commercial available antiserum and our own antiserum. Additionally, in patients and controls from the second comparison, DNA based HLA class II typing for DRB1 and DQB1 was performed using our modified PCR-sequence specific oligonucleotide (PCR-SSO) procedure. $^{32} 33$

STATISTICAL ANALYSIS

All data were analysed using the computer programme Excel for windows (v 5.0). Calculating phenotype frequencies and statistical data processing for the $\chi^{2}$ test were performed using the computer program SPSS/PC (v 6.0.1), and Fisher's exact test was used where appropriate. $\mathrm{p}$ values provided by the $\chi^{2}$ or Fisher's exact test were corrected by multiplying by the number of comparisons made (pc) according to the recommendations by Svejgaard and Ryder. ${ }^{34}$ This is necessary if one group is tested because $p$ values less than 0.05 will occur by chance without a true association when multiple comparisons are made. Thus in the first part of our study we multiplied by 57 and in the second part of the study we multiplied by 62 . However, the multiplication process can be circumvented when a second group of patients is analysed and $p$ values from the initial analysis are confirmed in the second group. ${ }^{10}$

\section{Results}

HLA FREQUENCY: FIRST PATIENT GROUP VERSUS FIRST CONTROL GROUP

Comparing phenotype frequencies of HLA class I (table 1) and class II (table 2) antigens in 69 patients with $\mathrm{HCV}$ induced liver cirrhosis with 331 blood and organ donors (control group 1), we found decreased frequencies of HLA-DR5 (12.3\% v 31.8\%; $\mathrm{p}=0.001$, relative risk $(\mathrm{RR})=0.3)$ and $\mathrm{DQ} 3(39.5 \%$ v $59.6 \%$; $\mathrm{p}<0.029, \mathrm{RR}=0.44$ ) in patients with $\mathrm{HCV}$ induced liver cirrhosis. Increased frequencies were found for A 19 (30.4\% v 18.1\%; $\mathrm{p}=0.032$, $\mathrm{RR}=1.98), \mathrm{B} 35 \quad(24.6 \%$ v $14.2 \% ; \mathrm{p}=0.049$, $\mathrm{RR}=1.98), \mathrm{B} 37 \quad(7.2 \%$ v $1.8 \% ; \mathrm{p}=0.035$, $\mathrm{RR}=4.23), \mathrm{Cw} 4(32.8 \%$ v $19.8 \% ; \mathrm{p}=0.035$, $\mathrm{RR}=1.98)$, and DR3 (30.8\% v $18.5 \%$; $\mathrm{p}=0.038, \mathrm{RR}=1.96)$. However, there were no statistically significant differences in phenotype frequency after statistical correction by multiplying $p$ values by the number of HLA antigens $(\mathrm{n}=57)$ tested.

HLA FREQUENCY: SECOND PATIENT GROUP VERSUS SECOND CONTROL GROUP

In a second comparison we analysed data for HLA typing by DNA analysis in a second group of 39 patients with HCV induced liver cirrhosis and 170 blood donors (control group 2) (tables 3, 4). In this analysis we found decreased frequencies of HLA-DRB $1{ }^{\star} 11$ $(7.7 \%$ v $22.4 \% ; \mathrm{p}=0.04, \mathrm{RR}=0.29)$ and HLA$\mathrm{DQB} 1{ }^{\star} 03 \quad(38.5 \% \quad v \quad 58.8 \% ; \mathrm{p}=0.033$, $R R=0.53$ ), and an increased frequency for HLA-B8 (40.6\% v 20.6\%; $\mathrm{p}=0.027, \mathrm{RR}=2.64)$ in patients with $\mathrm{HCV}$ induced liver cirrhosis. If we subdivided HLA-DQB ${ }^{\star} 03$ into HLADQB ${ }^{\star} 0301$ and $\mathrm{DQB} 1{ }^{\star} 0302$, none of these alleles was significantly different (table 5). Likewise, the associated haplotypes HLADR4-DQB $1{ }^{\star} 0301 \quad(2.5 \%$ v $6.4 \% ; \mathrm{p}=0.573$, $\mathrm{RR}=0.39)$ and HLA-DR4-DQB1 ${ }^{\star} 0302$ $(10.2 \%$ v $16.7 \% ; \mathrm{p}=0.375, \mathrm{RR}=0.58)$ were not significantly different. No statistical difference in this analysis was detected after correction. Thus HLA-DR5/DRB1*11 and HLA-DQ3 / DQB ${ }^{\star}{ }^{\star} 03$ were the only antigens/alleles found to be significantly lower in both studies, indicating an important role in disease protection. As with the first part of the study, no class 
Table 1 HLA class I frequencies of serologically typed patients with hepatitis $C$ virus (HCV) induced end stage liver disease versus blood and organ donors (control group 1)

\begin{tabular}{|c|c|c|c|c|c|}
\hline & \multicolumn{2}{|c|}{$\begin{array}{l}\text { Blood and organ } \\
\text { donors }\end{array}$} & \multicolumn{2}{|c|}{$\begin{array}{l}\text { HCV induced end } \\
\text { stage liver cirrhosis }\end{array}$} & \multirow[b]{2}{*}{$p$ Value } \\
\hline & $n$ & $\%$ & $n$ & $\%$ & \\
\hline $\mathrm{A} 1$ & 82 & 24.8 & 13 & 18.8 & NS \\
\hline $\mathrm{A} 2$ & 176 & 53.2 & 32 & 46.4 & NS \\
\hline A3 & 99 & 29.9 & 14 & 20.3 & NS \\
\hline A9 & 66 & 19.9 & 20 & 29.0 & NS \\
\hline A10 & 42 & 12.7 & 6 & 8.7 & NS \\
\hline A11 & 31 & 9.4 & 10 & 14.5 & NS \\
\hline$A 19$ & 60 & 18.1 & 21 & 30.4 & 0.032 \\
\hline \multirow[t]{2}{*}{ A28 } & 34 & 10.3 & 8 & 11.6 & NS \\
\hline & 331 & & 69 & & \\
\hline B5 & 48 & 14.5 & 7 & 10.1 & NS \\
\hline B7 & 88 & 26.6 & 16 & 23.2 & NS \\
\hline B8 & 51 & 15.4 & 16 & 23.2 & NS \\
\hline B12 & 96 & 29.0 & 24 & 34.8 & NS \\
\hline B13 & 22 & 6.6 & 7 & 10.1 & NS \\
\hline B14 & 16 & 4.8 & 3 & 4.3 & NS \\
\hline B15 & 48 & 14.5 & 6 & 8.7 & NS \\
\hline B16 & 34 & 10.3 & 2 & 2.9 & NS \\
\hline B17 & 27 & 8.2 & 5 & 7.2 & NS \\
\hline B18 & 33 & 10.0 & 4 & 5.8 & NS \\
\hline B21 & 17 & 5.1 & 4 & 5.8 & NS \\
\hline B22 & 20 & 6.0 & 3 & 4.3 & NS \\
\hline B27 & 22 & 6.6 & 5 & 7.2 & NS \\
\hline B35 & 47 & 14.2 & 17 & 24.6 & 0.049 \\
\hline B37 & 6 & 1.8 & 5 & 7.2 & 0.035 \\
\hline B40 & 48 & 14.5 & 7 & 10.1 & NS \\
\hline B41 & 4 & 1.2 & & 0.0 & NS \\
\hline B42 & 3 & 0.9 & & 0.0 & NS \\
\hline B47 & & 0.0 & & 0.0 & NS \\
\hline B53 & & 0.0 & & 0.0 & NS \\
\hline \multirow[t]{2}{*}{ B70 } & 2 & 0.6 & & 0.0 & \\
\hline & 331 & 100.0 & 69 & & \\
\hline Cw1 & 26 & 8.7 & 3 & 4.7 & NS \\
\hline Cw2 & 27 & 9.1 & 4 & 6.3 & NS \\
\hline Cw3 & 97 & 32.6 & 14 & 21.9 & NS \\
\hline Cw4 & 59 & 19.8 & 21 & 32.8 & 0.035 \\
\hline Cw5 & 46 & 15.4 & 11 & 17.2 & NS \\
\hline Cw6 & 54 & 18.1 & 18 & 28.1 & NS \\
\hline Cw7 & 140 & 47.0 & 27 & 42.2 & NS \\
\hline \multirow[t]{2}{*}{ Cw8 } & 11 & 3.7 & 1 & 1.6 & NS \\
\hline & 298 & & 64 & & \\
\hline
\end{tabular}

Table 2 HLA class II frequencies of serologically typed patients with hepatitis $C$ virus (HCV) induced end stage liver disease versus blood and organ donors (control group 1)

\begin{tabular}{|c|c|c|c|c|c|}
\hline & \multicolumn{2}{|c|}{$\begin{array}{l}\text { Blood and organ } \\
\text { donors }\end{array}$} & \multicolumn{2}{|c|}{$\begin{array}{l}\text { HCV induced end } \\
\text { stage liver cirrhosis }\end{array}$} & \multirow[b]{2}{*}{$p$ Value } \\
\hline & $n$ & $\%$ & $n$ & $\%$ & \\
\hline DR1 & 49 & 14.8 & 12 & 18.5 & NS \\
\hline DR2 & 109 & 33.0 & 17 & 26.2 & NS \\
\hline DR3 & 61 & 18.5 & 20 & 30.8 & 0.038 \\
\hline DR4 & 86 & 26.1 & 14 & 21.5 & NS \\
\hline DR5 & 105 & 31.8 & 8 & 12.3 & 0.001 \\
\hline DR6 & 99 & 30.0 & 21 & 32.3 & NS \\
\hline DR7 & 87 & 26.4 & 24 & 36.9 & NS \\
\hline DR8 & 18 & 5.5 & 1 & 1.5 & NS \\
\hline DR9 & 1 & 0.3 & & 0.0 & NS \\
\hline \multirow{2}{*}{ DR10 } & 3 & 0.9 & 2 & 3.1 & NS \\
\hline & 330 & & 65 & & \\
\hline DQ1 & 179 & 65.1 & 27 & 71.1 & NS \\
\hline DQ2 & 99 & 36.0 & 21 & 55.3 & NS \\
\hline$D Q 3$ & 164 & 59.6 & 15 & 39.5 & 0.029 \\
\hline \multirow[t]{2}{*}{ DQ4 } & 9 & 3.3 & & & NS \\
\hline & 275 & & 38 & & \\
\hline
\end{tabular}

I allele was found to be significantly different between patients and controls.

We also performed an analysis to investigate secondary association and linkage associations such as HLA-DR4-DQB ${ }^{\star}{ }^{\star} 0302$. However, none of the analyses showed a significant association (data not shown); HLA-DR11 was just significantly lower after exclusion of HLA$\mathrm{DQB} 1{ }^{\star} 0302(\mathrm{p}=0.049)$.
Table 3 HLA class I frequencies of patients with hepatitis $C$ virus $(H C V)$ induced end stage liver disease $(n=32)$ versus blood donors $(n=170$, control group 2$)$

\begin{tabular}{|c|c|c|c|c|c|}
\hline & \multicolumn{2}{|c|}{ Blood donors } & \multicolumn{2}{|c|}{$\begin{array}{l}\text { HCV induced end } \\
\text { stage liver cirrhosis }\end{array}$} & \multirow[b]{2}{*}{$p$ Value } \\
\hline & $n$ & $\%$ & $n$ & $\%$ & \\
\hline $\mathrm{A} 1$ & 61 & 35.9 & 13 & 40.6 & NS \\
\hline A2 & 81 & 47.6 & 13 & 40.6 & NS \\
\hline A3 & 57 & 33.5 & 12 & 37.5 & NS \\
\hline A9 & 28 & 16.5 & 7 & 21.9 & NS \\
\hline A10 & 23 & 13.5 & 2 & 6.3 & NS \\
\hline A11 & 11 & 6.5 & 3 & 9.4 & NS \\
\hline A19 & 42 & 24.7 & 4 & 12.5 & NS \\
\hline \multirow[t]{2}{*}{ A 28} & 17 & 10.0 & 2 & 6.3 & NS \\
\hline & 170 & & 32 & & \\
\hline B5 & 11 & 6.5 & 5 & 15.6 & NS \\
\hline B7 & 52 & 30.6 & 9 & 28.1 & NS \\
\hline B8 & 35 & 20.6 & 13 & 40.6 & 0.027 \\
\hline B12 & 39 & 22.9 & 4 & 12.5 & NS \\
\hline B13 & 10 & 5.9 & 2 & 6.3 & NS \\
\hline B14 & 7 & 4.1 & 2 & 6.3 & NS \\
\hline B15 & 24 & 14.1 & 1 & 3.1 & NS \\
\hline B16 & 9 & 5.3 & 1 & 3.1 & NS \\
\hline B17 & 20 & 11.8 & 2 & 6.3 & NS \\
\hline B18 & 16 & 9.4 & 1 & 3.1 & NS \\
\hline B21 & 5 & 2.9 & 1 & 3.1 & NS \\
\hline B22 & 11 & 6.5 & 2 & 6.3 & NS \\
\hline B27 & 22 & 12.9 & 2 & 6.3 & NS \\
\hline B35 & 25 & 14.7 & 9 & 28.1 & NS \\
\hline B37 & 4 & 2.4 & 1 & 3.1 & NS \\
\hline B40 & 24 & 14.1 & 5 & 15.6 & NS \\
\hline B41 & 4 & 2.4 & 0 & 0.0 & NS \\
\hline B47 & 3 & 1.8 & 0 & 0.0 & NS \\
\hline \multirow[t]{2}{*}{ B48 } & 1 & 0.6 & 0 & 0.0 & NS \\
\hline & 170 & & 32 & & \\
\hline Cw1 & 13 & 7.6 & 1 & 3.2 & NS \\
\hline $\mathrm{Cw} 2$ & 25 & 14.7 & 2 & 6.5 & NS \\
\hline Cw3 & 47 & 27.7 & 8 & 25.8 & NS \\
\hline $\mathrm{Cw} 4$ & 27 & 15.9 & 10 & 32.3 & NS \\
\hline Cw5 & 26 & 15.3 & 2 & 6.5 & NS \\
\hline Cw6 & 34 & 20.0 & 4 & 12.9 & NS \\
\hline Cw7 & 91 & 53.5 & 18 & 58.1 & NS \\
\hline \multirow[t]{2}{*}{ Cw8 } & 6 & 3.5 & 2 & 6.5 & NS \\
\hline & 170 & & 31 & & \\
\hline
\end{tabular}

Table 4 HLA class II frequencies of patients with hepatitis $C$ virus ( $H C V)$ induced end stage liver disease $(n=39)$ versus blood donors $(n=170$, control group 2$)$ who were typed by a polymerase chain reaction-sequence specific oligonucleotide procedure

\begin{tabular}{|c|c|c|c|c|c|}
\hline & \multicolumn{2}{|c|}{ Blood donors } & \multicolumn{2}{|c|}{$\begin{array}{l}\text { HCV induced end } \\
\text { stage liver cirrhosis }\end{array}$} & \multirow[b]{2}{*}{ p Value } \\
\hline & $n$ & $\%$ & $n$ & $\%$ & \\
\hline $\mathrm{DRB} 1 \star 1$ & 31 & 17.6 & 5 & 12.8 & NS \\
\hline $\mathrm{DRB} 1{ }^{\star} 2$ & 68 & 40.0 & 12 & 30.8 & NS \\
\hline $\mathrm{DRB} 1 * 3$ & 41 & 24.1 & 12 & 30.8 & NS \\
\hline $\mathrm{DRB} 1^{\star} 4$ & 42 & 24.7 & 5 & 12.8 & NS \\
\hline $\mathrm{DRB} 1{ }^{\star} 7$ & 41 & 24.1 & 13 & 33.3 & NS \\
\hline $\mathrm{DRB} 1 \star 8$ & 11 & 6.5 & 1 & 2.6 & NS \\
\hline $\mathrm{DRB} 1^{\star} 9$ & 4 & 2.4 & 2 & 5.1 & NS \\
\hline DRB $1{ }^{\star} 10$ & & 0.0 & 1 & 2.6 & NS \\
\hline$D R B 1^{\star} 11$ & 38 & 22.4 & 3 & 7.7 & 0.04 \\
\hline DRB $1{ }^{\star} 12$ & 9 & 5.3 & 2 & 5.1 & NS \\
\hline DRB $1{ }^{\star} 13$ & 21 & 12.4 & 10 & 25.6 & NS \\
\hline \multirow[t]{2}{*}{$\mathrm{DRB} 1^{\star} 14$} & 11 & 6.5 & 4 & 10.3 & NS \\
\hline & 170 & & 39 & & \\
\hline $\mathrm{DQB} 1{ }^{\star} 02$ & 64 & 37.6 & 21 & 53.8 & NS. \\
\hline$D Q B 1^{\star} 03$ & 100 & 58.8 & 15 & 38.5 & 0.033 \\
\hline DQ̄B $1{ }^{\star} 04$ & 11 & 6.5 & 3 & 7.7 & NS \\
\hline DQB $1{ }^{\star} 05$ & 49 & 28.8 & 9 & 23.1 & NS \\
\hline \multirow[t]{2}{*}{ DQB $1 * 06$} & 79 & 46.5 & 19 & 48.7 & NS \\
\hline & 170 & & 39 & & \\
\hline
\end{tabular}

HLA FREQUENCY IN PATIENTS WITH OR WITHOUT HCC

In patients with HCC $(n=22)$ in the explanted liver we found an increase in HLA-B37 (22.2\% $v 1.8 \% ; \mathrm{p}=0.02, \mathrm{RR}=12.44)$ prior to compulsory multiplication and HLA-DR1 was found 
Table 5.DQB1*03 allele frequencies of patients with hepatitis $C$ virus (HCV) induced end stage liver disease versus blood donors, who were typed by a polymerase chain reaction-sequence specific oligonucleotide procedure

\begin{tabular}{|c|c|c|c|c|c|}
\hline & \multicolumn{2}{|c|}{ Blood donors } & \multicolumn{2}{|c|}{$\begin{array}{l}\text { HCV induced end } \\
\text { stage liver } \\
\text { cirrhosis }\end{array}$} & \multirow[b]{2}{*}{$p$ Value } \\
\hline & $n$ & $\%$ & $n$ & $\%$ & \\
\hline $\mathrm{DQB} 1{ }^{\star} 0301$ & 56 & 32.9 & 8 & 20.5 & NS \\
\hline DQB $1{ }^{\star} 0302$ & 31 & 18.2 & 4 & 10.3 & NS \\
\hline $\mathrm{DQB} 1 * 3032$ & 20 & 11.8 & 5 & 12.8 & NS \\
\hline \multirow[t]{2}{*}{$\mathrm{DQB} 1{ }^{\star} 0304$} & 1 & 0.6 & 0 & & NS \\
\hline & 100 & & 15 & & \\
\hline
\end{tabular}

less frequently $(4.3 \%$ v $30.8 \% ; \mathrm{p}=0.05$, $R R=0.082)$. None remained significant after essential multiplication.

\section{HLA FREQUENCY IN RELATION TO HCV}

GENOTYPES

HLA patterns did not differ remarkably among patient groups divided on the basis of different HCV genotypes. The only difference was for patients with genotype $1 \mathrm{a}$ who had increased frequencies of HLA-B12 (5/8 (62.5\%)) compared with those with genotype $1 \mathrm{~b}(12 / 53$ $(22.6 \%) ; \mathrm{p}=0.032, \mathrm{RR}=5.694)$ and all others $(16 / 65(24 \%) ; \mathrm{p}=0.039, \quad \mathrm{RR}=5.104)$, and HLA-B16 (3/8 (37.5\%) v 0/53 (0\%; p=0.002, $\mathrm{RR}=\mathrm{na})$ and $0 / 65, \leqslant 0.001, \mathrm{RR}=\mathrm{na})$. However, no significance difference was detected after correction.

HLA FREQUENCY IN RELATION TO PATIENT SEX HLA patterns did not differ in male and female patients.

\section{Discussion}

Based on earlier results from European studies, ${ }^{16182021}$ we assumed that the phenotype frequency of HLA-DR5 antigen and the corresponding allele DRB1*11 would be significantly decreased in patients with $\mathrm{HCV}$ induced liver cirrhosis compared with controls. As expected, in two independent comparisons we found that the HLA-DR5 antigen or the corresponding HLA-DRB1 ${ }^{\star} 11$ allele was significantly less frequent in patients with $\mathrm{HCV}$ induced end stage liver cirrhosis. In addition, HLA-DQB ${ }^{\star} 03$ was found less frequently in patients with $\mathrm{HCV}$ induced end stage liver disease. In common with HLA-DRB $1^{\star} 11$, HLADQB $1^{\star} 03$ has been reported to be less frequent in patients with viral clearance. ${ }^{20}{ }^{21}$

Whether HLA-DRB $1^{\star} 11$ or $\mathrm{DQB} 1{ }^{\star} 03$ is the more relevant factor is difficult to determine as HLA-DRB $1^{\star} 11$ is in strong linkage disequilibrium with $\mathrm{DQB} 1^{\star} 0301$. Neither HLA-DRB $1{ }^{\star} 11$ nor HLA-DRB $1{ }^{\star} 03$ remained significantly different after exclusion of the other. Some studies found $\mathrm{DQB} 1{ }^{\star} 03$ to be relevant without identifying $\mathrm{DRB} 1^{\star} 11$ as a relevant cofactor, ${ }^{25}$ while those identifying HLADRB $1^{\star} 11$ as a relevant factor also found DQB ${ }^{\star} 03$ to be relevant. ${ }^{20}{ }^{21}$ This would argue for a more important role of $\mathrm{DQB} 1{ }^{\star} 03$ versus DR ${ }^{\star} 11$. Although HLA-DRB ${ }^{\star} 11$ and $\mathrm{DQB} 1^{\star} 03$ have most frequently been associated with resolving $\mathrm{HCV}$ infection, ${ }^{20} 21$ 35-37 other alleles have also been identified in individual studies. ${ }^{24} 38$

However, these studies were performed in patients selected because of their known HCV status. In two studies performed in women selected by their rhesus status and infected with a uniform source of $\mathrm{HCV}$, neither HLA$\mathrm{DRB} 1{ }^{\star} 11$ nor $\mathrm{DQB} 1{ }^{\star} 03$ was associated with viral persistence. Only HLA-DRB $1^{\star} 01$ was found to be associated with viral clearance. ${ }^{39} 40$

We have recently been involved in a large European multicentre study demonstrating that HLA-DR ${ }^{\star} 11$ and HLA-DQB ${ }^{\star} 0301$ are the most prominent factors in viral clearance of $\mathrm{HCV}^{41}$ Comparing all of our patients with those with persistent hepatitis $\mathrm{C}$ from the European study ${ }^{41}$ supports the relevance of HLA-DR5 for lower disease progression. We found 13 of 104 patients $(12.5 \%)$ to be HLA-DR5 positive in the study reported here, only among patients with very late stage $\mathrm{HCV}$ induced liver disease, compared with 39 of 170 (22.9\%) in the European study ( $p=0.032$ uncorrected $\chi^{2}$ test). This shows that HLA-DR5 is even less frequent in patients with the most advanced form of chronic hepatitis C compared with those selected only on the basis of positive HCV RNA status for more than six months. This would indicate that HLADRB $1{ }^{\star} 11$ and DQB $1{ }^{\star} 03$ alleles are associated with a favourable outcome of chronic hepatitis $\mathrm{C}$ instead of viral clearance. Perhaps the low frequency of HLA-DRB $1^{\star} 11$ and $\mathrm{DQB} 1{ }^{\star} 03$ in many studies analysing patients with replicative hepatitis C compared with patients with self limited HCV infection may be due to over representation of patients with more progressive disease compared with those with none or minimal disease. This view is supported by studies in European patients with different stages of $\mathrm{HCV}$ disease. $^{1842}$

The relevance of the immune system in ameliorating $\mathrm{HCV}$ infection is also supported by the more rapid disease progression in HIV infected $^{43}$ and agammaglobulinaemic patients. ${ }^{44}{ }^{45}$ Both diseases show a disturbance in CD4+ T cell competence or antibody production. In agreement with this hypothesis, viral clearance was found to be associated with either a vigorous $\mathrm{CD} 4+\mathrm{T}$ cell reaction ${ }^{46}$ or high antibody titres. ${ }^{47}$ However, reactivation of hepatitis can occur after discontinuation of immunosuppressive treatment. $^{48}$ Thus while the CD4+ $\mathrm{T}$ cell response may contribute to amelioration of the disease, ${ }^{49} \mathrm{CD} 8+$ cytotoxic $\mathrm{T}$ cells may contribute to hepatocellular damage. This is in agreement with data showing a significant correlation of $\mathrm{CD} 8+\mathrm{T}$ cell numbers and alanine aminotransferase levels. ${ }^{50}$

Apart from direct involvement in the pathogenesis of $\mathrm{HCV}$ infection, HLA DRB $1^{\star} 11$ may be in linkage disequilibrium with an as yet unidentified disease predisposing gene. ${ }^{51}$ However, no association was found between chronic hepatitis $\mathrm{C}$ and the TAP and LMP2 polymorphic alleles, ${ }^{52}$ which are located close to the HLA-DQ locus.

Most studies published so far only included HLA class II typing. Although we included HLA class I antigens in this analysis, no antigen was significantly associated with $\mathrm{HCV}$ induced 
end stage liver disease. Similarly, analysis of HLA pattern in relation to HCV genotype or the presence or absence of HCC did not reveal any major influences.

In conclusion, our results show that the presence of HLA-DR5 antigen/HLADRB1*11 and HLA-DQ3/HLA-DQB ${ }^{\star} 03$, respectively, is associated with a reduced risk of developing end stage liver disease induced by $\mathrm{HCV}$ infection in Caucasians, independent of HCV genotype.

We are grateful to the staff of the HLA Typing Laboratory, Department for Transfusion Medicine, Hannover Medical School, who performed the serological HLA typing of the patients, and we thank Dr Peter Donaldson for valuable comments on the paper. We thank the physicians and nurses who provided us with specimens and clinical data. Supported by the SFB265, project C5. Part of this work was presented at the IX Triennial Internal Symposium on Viral Hepatitis and Liver Disease, Rome, 21-25 April 1996. This work contains part of the theses of Miss Angela Grundey and Mrs Andrea Berning-Haag.

1 Nishioka K, Watanabe J, Furuta S, et al. Antibody to the hepatitis $\mathrm{C}$ virus in acute and chronic liver disease in Japan. Liver 1991,11:65-70.

2 Tremolada F, Casarin C, Tagger A, et al. Antibody to hepatitis $\mathrm{C}$ virus in post transfusion hepatitis. Ann Intern Med 1991;114:277-81.

3 Alter MJ. Epidemiology of hepatitis C in the West. Semin Liver Dis 1995;15:5-14

4 Tillmann HL, Manns MP. Mode of hepatitis C virus infection, epidemiology, and chronicity rate in the general population and risk groups. Dig Dis Sci 1996;41:27-40S.

5 Tong MS, El-Farra NS, Reikes AR, et al. Clinical outcomes after transfusion-associated hepatitis C. $N$ Engl $f \mathrm{Med}$ 1995;332:1463-6.

6 Lau JYN, Davis GL, Kniffen J, et al. Significance of serum hepatitis C virus RNA levels in chronic hepatitis C. Lancet 1993;341:1501-4.

7 Mosnier JF, Degott C, Marcellin P, et al. The intraportal lymphoid nodule and its environment in chronic active hepatitis C: An immunohistochemical study. Hepatology 1993;17:366-71

8 Yuki N, Hayashi N, Takehara T, et al. Serum hepatitis C virus RNA levels and liver injury in volunteer blood donors. Am $\mathcal{F}$ Gastroenterol 1994;89:1462-6.

9 Sheehan MM, Doyle CT, Whelton M, et al. Hepatitis C virus liver disease in women infected with contaminated anti-D immunoglobulin. Histopathology 1997:30:512-17.

10 Thursz MR, Kwiatkowski D, Allspp CEM, et al. Association between a MHC Class II allele and clearance of hepatitis B virus in Gambia. N Engl f Med 1995;332:1065-9.

11 Karayiannis P, Alexopoulou A, Hadziyannis S, et al. Fulminant hepatitis associated with hepatitis B virus e antigennegative infection: importance of host factors. Hepatology negative infection:

12 Steel CM, Ludlam CA, Beatson D, et al. HLA haplotype A1 B8 DR3 as a risk factor for HIV-related disease. Lancet 1988;i:1185-8.

13 Malkovsky M. HLA and the natural history of HIV infection. Lancet 1996;348:142-3.

14 Verdon R, Pol S, Landais P, et al. Absence of association between HLA antigens and chronicity of viral hepatitis in haemodialyzed patients. F Hepatol 1994;21:388-93.

15 Vitte RL, Fortier G, Richardet JP, et al. HLA antigens in patients with chronic hepatitis C. Tissue Antigens 1995;45: 356-61.

16 Chen DF, Endres W, Kliem V, et al. No significant influence of HLA determinants on susceptibility to hepatitis $\mathrm{C}$ virus infection in Caucasian patients with end-stage renal disease. Liver 1996;16:384-9.

17 Czaja AJ, Carpenter H, Santrach PJ, et al. DR human leukocyte antigens and disease severity in chronic hepatitis C. $\mathcal{F}$ Hepatol 1996;24:666-73.

18 Peano G, Menardi G, Ponzetto A, et al. HLA-DR5 antigen a genetic factor influencing the outcome of hepatitis $\mathrm{C}$ virus genetic factor influencing the outcome of hep
infection? Arch Intern Med 1994;154:2733-6

19 Zavaglia C, Bortolon C, Ferrioli G, et al. HLA typing in chronic type B, D and C hepatitis. F Hepatol 1996;24:65865.

20 Minton EJ, Smillie D, Neal KR, et al. Association between MHC class II alleles and clearance of circulating hepatitis $\mathrm{C}$ virus. Members of the Trent Hepatitis C Virus Study Group. F Infect Dis 1998;178:39-44.

21 Alric L, Fort M, Izopet J, et al. Genes of the major histocompatibility complex class II influence the outcome of hepatitis C virus infection. Gastroenterology 1997:113: $1675-85$

22 Aikawa T, Kojima M, Onishi H, et al. HLA DRB1 and DQB1 alleles and haplotypes influencing the progression of hepatitis C. 7 Med Virol 1996;49:274-8.

23 Higashi Y, Kamikawaji N, Suko H, et al. Analysis of HLA alleles in Japanese patients with cirrhosis due to hepatitis C. alleles in Japanese patients with cirrhosis

24 Kuzushita N, Hayashi N, Katayama K, et al. Increased frequency of HLA-DR13 in hepatitis $C$ virus carriers with persistently normal ALT levels. f Med Virol 1996;48:1-7.
25 Cramp ME, Carucci P, Underhill J, et al. Association between HLA class II genotype and spontaneous clearance of hepatitis C viraemia. F Hepatol 1998;29:207-13.

26 Höhler T, Gerken G, Notghi A, et al. MHC class II genes influence the susceptibility to chronic active hepatitis C. $\mathcal{F}$ Hepatol 1997;27:259-64.

27 Rehermann B, Seifert U, Tillmann HL, et al. Serological pattern of hepatitis $\mathrm{C}$ virus recurrence after liver transplantation. F Hepatol 1996;24:15-20.

28 Okamoto $\mathrm{H}$, Kobata S, Tokita $\mathrm{H}$, et al. A second-generation method of genotyping hepatitis $\mathrm{C}$ virus by the polymerase chain reaction with sense and antisense primers deduced from the core gene. F Virol Methods 1996;57:31-45.

29 Stuyver L, Rossau R, Wyseur A, et al. Typing of hepatitis C virus isolates and characterisation of new subtypes using a line probe assay. F Gen Virol 1993;74:1093-102.

30 Michitaka K, Durazzo M, Tillmann HL, et al. Analysis of hepatitis $\mathrm{C}$ virus genome in patients with autoimmune hepatitis type 2. Gastroenterology 1994;106:1603-10.

31 Tillmann H, Trautwein C, Walker D, et al. 1995. Clinical relevance of mutations in the precore genome of the hepatitis B virus. Gut 1994:37:568-73.

32 Chen DF, Endres W, Meyer SA, et al. A polymerase chain reaction-sequence-specific oligonucleotide procedure for HLA class II typing using biotin- and digoxigenin-labeled probes simultaneously in hybridization. Hum Immunol 1994;39:25-30.

33 Chen DF, Endres W, Meyer SA, et al. A simplified PCR-SSO procedure for DQA- and DQB-typing: Hybridizing one membrane with two probes simultaneously. Hum Immunol 1996;46:120-3.

34 Svejgaard A, Ryder LP. HLA and disease associations: Detecting the strongest association. Tissue Antigens 1994; 43:18-27.

35 Tibbs C, Donaldson P, Underhill J, et al. Evidence that the HLA DQA ${ }^{\star} 03$ allele confers protection from chronic HCV-infection in Northern European Caucasoids. Hepatology 1996;24:1342-5.

36 Mangia A, Gentile R, Cascavilla I, et al. HLA class II favors clearance of HCV infection and progression of the chronic liver damage. F Hepatol 1999;30:984-9.

37 Wawrzynowicz-Syczewska M, Underhill JA, Clare MA, et al. HLA class II genotypes associated with chronic hepatitis C virus infection and response to alpha-interferon treatment in Poland. Liver 2000;20:234-9.

38 Lechmann M, Schneider EM, Giers G, et al. Increased frequency of the HLA-DR15 (B1*15011) allele in German patients with self-limited hepatitis C virus infection. Eur $\mathcal{F}$ Clin Invest 1999, 29:337-43.

39 Barrett S, Ryan E, Crowe J. Association of the HLA$\mathrm{DRB} 1{ }^{\star} 01$ allele with spontaneous viral clearance in an Irish cohort infected with hepatitis $C$ virus via contaminated anti-D immunoglobulin. F Hepatol 1999;30:979-83.

40 Fanning LJ, Levis J, Kenny-Walsh E, et al. Viral clearance in hepatitis C (1b) infection: relationship with human leukocyte antigen class II in a homogeneous population. Hepatology 2000;31:1334-7.

41 Thursz M, Yallop R, Goldin R, et al. Influence of MHC class II genotype on outcome of infection with hepatitis $\mathrm{C}$ virus. The HENCORE group. Hepatitis C European Network for Cooperative Research. Lancet 1999;354:2119-24.

42 Asti M, Martinetti M, Zavaglia C et al. Human leukocyte antigen class II and III alleles and severity of hepatitis C virus-related chronic liver disease. Hepatology 1999;29: 1272-9.

43 Ockenga J, Tillmann HL, Trautwein C, et al. Hepatitis B and $\mathrm{C}$ in HIV-infected patients. Prevalence and prognostic value. F Hepatol 1997;27:18-24.

44 Bjoro K, Froland SS, Yun Z, et al. Hepatitis C infection in patients with primary hypogammaglobulinemia after treatment with contaminated immune globulin. $N$ Engl f Med 1994;331:1607-11.

45 Christie JM, Healey CJ, Watson J, et al. Clinical outcome of hypogammaglobulinaemic patients following outbreak of acute hepatitis C: 2 year follow-up. Clin Exp Immunol 1997; 110:4-8.

46 Diepolder HM, Zachoval R, Hoffmann RM, et al. Possible mechanism involving T-lymphocyte response to nonstructural protein 3 in viral clearance in acute hepatitis C virus infection. Lancet $1995 ; 346: 1006-7$.

47 Ishii K, Rosa D, Katayama T, et al. High titers of antibodies inhibiting the binding of envelope to human cells correlate with natural resolution of chronic hepatitis C. Hepatology 1998;28:1117-20.

48 Gruber A, Lundberg LG, Bjorkholm M. Reactivation of chronic hepatitis $\mathrm{C}$ after withdrawal of immunosuppressive chronic hepatitis C after withdrawal of in

49 Botarelli P, Brunetto MR, Minutello MA, et al. T-lymphocyte response to hepatitis $\mathrm{C}$ virus in different clinical courses of infection. Gastroenterology 1993;104: $580-7$

50 Ballardini G, Groff P, Pontisso P, et al. Hepatitis C virus (HCV) genotype, tissue $\mathrm{HCV}$ antigens, hepatocellular expression of HLA-A, B, C, and intercellular adhesion-1 molecules. Clues to pathogenesis of hepatocellular damage and response to interferon treatment in patients with chronic hepatitis C. $\mathcal{F}$ Clin Invest 1997;95:2067-75.

51 Rigas B. HLA and disease: the case of gastric cancer. Gastroenterology 1996;111:523-6.

52 Höhler T, Gerken G, Schneider PM, et al. Antigenprocessing polymorphisms in chronic hepatitis C infection. Exp Clin Immunogenet 1996;13:7-11. 